JIIA, VOLUME 6, No. 1, FEBRUARI 2018

\title{
PARTISIPASI PETANI DALAM PROGRAM UPSUS PAJALE DI KECAMATAN RAWA JITU SELATAN KABUPATEN TULANG BAWANG
}

\author{
(Participation of farmers on Upsus Pajale Program in Rawa Jitu Selatan of Tulang Bawang Regency)
}

Destika Maulidiawati, Dewangga Nikmatullah, Rio Tedi Prayitno

Jurusan Agribisnis, Fakultas Pertanian, Universitas Lampung, J1. Prof. Dr. Soemantri Brojonegoro No. 1 Bandar Lampung, 35145. Telp 085658823220.e-mail: destikamaulidia@gmail.com

\begin{abstract}
This study aims to examine the implementation, the level of farmers' participation, and factors related to the level of participation in the Upsus Pajale program in South Rawa Jitu Sub-District of Tulang Bawang Regency. This study data was collected in January-February 2017 by envolving 54 farmers' respondents. This study was conducted by survey method and its data was analyzed descriptively and statistically by Rank Spearman Correlation. The results showed that factors related to farmers' participation in Upsus Pajale Program were production, group communication behavior and intensity of program socialization. Farmers' participation in planning activity was mostly $(59,26 \%)$ in moderate category, participation in implementation activity was mostly (83,3\%) in high category, participation in monitoring and evaluation activities was low (46,3\%) and participation in the utilization of development outcomes was high (100\%). In overall, most of farmers' participation in Upsus Pajale program in Rawa Jitu Selatan sub District wass moderate $(48,15 \%)$.
\end{abstract}

Key words: farmer, participation, Upsus Pajale

\section{PENDAHULUAN}

Kabupaten Tulang Bawang merupakan salah satu kabupaten di Provinsi Lampung yang menerapkan program Upsus Pajale. Jumlah produksi padi di Kabupaten Tulang Bawang berada pada posisi ke lima tertinggi dan jumlah produksi jagung di Kabupaten Tulang Bawang berada pada posisi kesepuluh tertinggi dibandingkan dengan kabupaten lain di Provinsi Lampung. Kecamatan Rawa Jitu Selatan merupakan salah satu kecamatan di kabupaten Tulang Bawang yang melaksanakan program Upsus Pajale. Rata-rata produksi padi tahun 2013-2015 di Kecamatan Rawa Jitu Selatan tertinggi bila dibandingkan dengan kecamatan lain yang ada di Kabupaten Tulang Bawang. Namun, rata-rata produksi jagung dan kedelai di Kecamatan Rawa Jitu Selatan tahun 2013-2015 tergolong rendah, yaitu sebesar 434,667 ton dan 25 ton. Hal ini terjadi karena kondisi lahan di Kecamatan Rawa Jitu Selatan merupakan lahan rawa dengan intensitas genangan air yang tinggi, sedangkan komoditas jagung dan kedelai tidak dapat tumbuh dan berkembang dengan intensitas air yang tinggi. Menurut Hartanti et all. (2012) pertambahan penduduk setiap tahunnya akan memunculkan masalah-masalah sosial seperti kemiskinan, kelaparan jika tidak diimbangi dengan terlaksananya pembangunan.
Salah satu faktor yang menentukan terlaksananya pembangunan adalah faktor manusia, maka partisipasi dan kerja sama dari masyarakat sangat diperlukan. Partisipasi masyarakat sangat diharapkan dalam pembangunan dari tahap perencanaan, tahap pelaksanaan, tahap pemanfaatan dan evaluasi sehingga akan dapat dilaksanakan pembangunan daerah yang benarbenar sesuai dengan kebutuhan dan aspirasi masyarakat. Partisipasi masyarakat merupakan langkah penting dalam upaya untuk mengetahui dan menganalisis kebutuhan serta masalah-masalah yang dialami masyarakat itu sendiri (Saputra 2015). Menurut Soehardjo yang dikutip oleh Tangkilisan (2007) menjelaskan bahwa dalam pembangunan partisipasi masyarakat, kerjasama secara sukarela merupakan kunci utama bagi keberhasilan pembangunan. Partisipasi berfungsi menumbuhkan kemampuan masyarakat untuk berkembang secara mandiri dalam usaha memperbaiki taraf hidup masyarakat. Partisipasi sangat berperan penting dalam pelaksanaan program pembangunan, karena tanpa adanya partisipasi dari masyarakat, suatu program tidak akan berjalan dengan baik.

Berdasarkan hal di atas, maka sejauhmana dan bagaimana partisipasi petani dalam Program Upsus Pajale di Kecamatan Rawa Jitu Selatan Kabupaten Tulang Bawang. Tujuan dari penelitian ini adalah 
mengkaji pelaksanaan Program Upsus Pajale dan tingkat partisipasi petani dalam Program Upsus Pajale serta faktor-faktor yang berhubungan dengan tingkat partisipasi petani dalam Program Upsus Pajale di Kecamatan Rawa Jitu Selatan Kabupaten Tulang Bawang.

\section{METODE PENELITIAN}

Metode penelitian yang digunakan adalah metode survei. Penelitian ini dilakukan di Kecamatan Rawa Jitu Selatan Kabupaten Tulang Bawang. Penentuan lokasi dilakukan secara sengaja (purposive) dengan pertimbangan bahwa Kecamatan Rawa Jitu Selatan merupakan kecamatan di Kabupaten Tulang Bawang yang menjalankan Program Upsus Pajale dan memiliki produksi padi tertinggi. Terdapat delapan Gapoktan di Kecamatan Rawa Jitu Selatan Kabupaten Tulang Bawang, dari delapan Gapoktan tersebut dipilih dua Gapoktan yang memiliki produksi padi tertinggi dan terendah, yaitu Gapoktan Hargo Rejo dan Gapoktan Yudha Karya Jitu.

Populasi penelitian adalah seluruh anggota kelompok tani yang tergabung dalam Gapoktan Hargo Rejo dan Gapoktan Yudha Karya Jitu. Gapoktan Hargo Rejo merupakan gapoktan yang memiliki produksi padi tertinggi. Anggota Gapoktan Hargo Rejo yang terdapat di Kecamatan Rawa Jitu Selatan sebanyak 16 kelompok tani dan dipilih dua kelompok tani yang memiliki produksi padi tertinggi dan terendah, yaitu kelompok tani Budi Karya dengan jumlah anggota sebanyak 30 petani dan kelompok tani Sri Murni dengan jumlah anggota sebanyak 25 petani.

Gapoktan Yudha Karya Jitu merupakan Gapoktan yang memiliki produksi padi terendah. Anggota Gapoktan Yudha Karya Jitu yang terdapat di Kecamatan Rawa Jitu Selatan sebanyak 18 kelompok tani dan dipilih dua kelompok tani yang memiliki produksi padi tertinggi dan terendah, yaitu kelompok tani Sido Mukti dengan jumlah anggota sebanyak 37 petani dan kelompok tani Ngudi Makmur dengan jumlah anggota sebanyak 23 petani. Penentuan jumlah sampel mengacu pada rumus Yamane. Berdasarkan rumus Yamane ' $\boldsymbol{V}$ "ncoro dan Riduwan 2008) maka total sampel 2 m penelitian adalah sebagai berikut :

$\mathrm{n}=\frac{\mathrm{N}}{\mathrm{Nd}^{2}+1}$.

$\mathrm{n}=\frac{115}{115(0,1)^{2}+1}$ $\mathrm{n}=54$ responden

Keterangan :
$\mathrm{n}=$ Unit sampel
$\mathrm{N}=$ Populasi
$\mathrm{d}=$
$\quad$ Presisi (ditetapkan 10\%dengan tingkat
$\quad$ kepercayaan $90 \%)$

Data yang digunakan dalam penelitian ini meliputi data primer dan data sekunder. Data primer diperoleh melalui wawancara langsung dengan responden penelitian menggunakan kuesioner. Data sekunder diperoleh dari dinas atau instansi terkait dan lembaga-lembaga yang berhubungan dengan penelitian ini. Pengumpulan data penelitian ini dilakukan pada bulan JanuariFebruari 2017. Metode pengambilan sampel yang digunakan adalah metode acak sederhana.

Metode analisis data yang digunakan untuk tujuan penelitian mengenai pelaksanaan dan tingkat partisipasi petani dalam program Upsus Pajale di Kecamatan Rawa Jitu Selatan Kabupaten Tulang Bawang adalah dengan menggunakan metode analisis deskriptif kualitatif, sedangkan untuk menganalisis faktor-faktor yang berhubungan dengan partisipasi petani dalam program Upsus Pajale digunakan statistik nonparametrik korelasi Rank Spearman (Siegel 2011) :

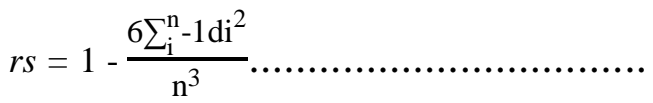

Keterangan :

rs : Penduga koefisien korelasi

di : Perbedaan setiap pasangan rank

n : Unit sampel

Kaidah pengambilan keputusan adalah :

1. Jika $\mathrm{t}$ hitung $<\mathrm{t}$ tabel maka tolak $\mathrm{H}_{1}$, pada $(\alpha)=$ 0,05 atau $(\alpha)=0,01$ berarti tidak terdapat hubungan antara kedua variabel yang diuji.

2. Jika $t$ hitung $\geq \mathrm{t}$ tabel maka terima $\mathrm{H}_{1}$, pada $(\alpha)$ $=0,05$ atau $(\alpha)=0,01$ berarti terdapat hubungan antara kedua variabel yang diuji.

Kegiatan partisipasi (Y) meliputi perencanaan kegiatan, pelaksanaan kegiatan, pemantauan dan evaluasi, serta pemanfaatan hasil-hasil pembangunan. Faktor-faktor yang diduga berhubungan dengan partisipasi petani dalam Program Upsus Pajale di Kecamatan Rawa Jitu Selatan Kabupaten Tulang Bawang adalah produksi (X1), tingkat motivasi petani (X2), perilaku komunikasi kelompok (X3) dan intensitas sosialisasi program (X4). Indikator 
pengukuran produksi adalah produksi padi dengan adanya kegiatan program Upsus Pajale dalam satu musim tanam. Indikator pengukuran motivasi adalah tingkat persistensi, devosi, tingkat aspirasi, tingkat kualifikasi dan sikap terhadap program. Indikator pengukuran perilaku komunikasi kelompok adalah frekuensi komunikasi dalam kelompok, media komunikasi, informasi komunikasi, sikap terhadap informasi dan media yang digunakan untuk menyebarkan informasi. Indikator pengukuran intensitas mengikuti sosialisasi program adalah frekuensi kegiatan sosialisasi yang diberikan kepada responden mengenai Program Upsus Pajale.

\section{HASIL DAN PEMBAHASAN}

\section{Kondisi Daerah Penelitian dan Karakteristik Responden}

Kecamatan Rawa Jitu Selatan merupakan salah satu kecamatan yang terdapat di Kabupaten Tulang Bawang. Jarak antara Kecamatan Rawa Jitu Selatan dengan Ibukota Kabupaten (Menggala) adalah $90 \mathrm{~km}$. Kecamatan Rawa Jitu Selatan terdiri dari Sembilan kampung. Salah satu kampung di Kecamatan Rawa Jitu Selatan merupakan pemekaran baru tahun 2009 yang memiliki wilayah muara sungai Pidada, yaitu Kampung Karya Cipta Abadi. Kecamatan Rawa Jitu Selatan terdiri dari 33 Dusun dengan luas wilayah 10.289 ha. Jumlah penduduk di Kecamatan Rawa Jitu Selatan pada tahun 2015 adalah 30.239 jiwa $(5.726 \mathrm{KK})$.

\section{Tingkat Partisipasi Petani (Variabel Y)}

Menurut Mardikanto (2010) partisipasi adalah keikutsertaan masyarakat dalam suatu kegiatan, baik keterlibatan masyarakat dalam bentuk fisik ataupun nonfisik. Partisipasi masyarakat merupakan faktor pendorong utama keberhasilan suatu program. Terdapat empat kegiatan yang menunjukkan partisipasi dalam kegiatan pembangunan, yaitu partisipasi dalam pengambilan keputusan, partisipasi dalam pelaksanaan kegiatan, partisipasi dalam pemantauan dan evaluasi, serta partisipasi dalam pemanfaatan hasil-hasil pembangunan. Dapat dilihat pada Tabel 1 rekapitulasi petani dalam program Upsus Pajale.

Berdasarkan Tabel 1 dapat dilihat bahwa rata-rata petani yang menjadi responden $(18,64 \%)$ memiliki tingkat partisipasi yang tergolong sedang dalam program Upsus Pajale di Kecamatan Rawa Jitu Selatan. Perencanaan kegiatan meliputi penentuan letak Jaringan Irigasi Tersier (JIT), waktu pembuatan JIT, perawatan JIT, jadwal tanam, varietas padi yang akan ditanam, teknis penanaman, dan pembersihan saluran air. Partisipasi dalam pelaksanaan kegiatan tergolong tinggi. Pelaksanaan kegiatan program Upsus Pajale meliputi kegiatan JIT, penyediaan bantuan benih, pupuk, alat dan mesin pertanian, penanaman padi hibrida serta jajar legowo. Partisipasi petani dalam pemantauan dan evaluasi kegiatan tergolong rendah. Rata-rata frekuensi kehadiran petani dalam evaluasi awal adalah satu kali, evaluasi saat kegiatan berlangsung adalah satu kali dan evaluasi akhir adalah satu kali. Partisipasi petani dalam evaluasi awal program Upsus Pajale meliputi letak JIT, kekurangan dan perawatan JIT,manfaat JIT, tata kelola dan tata letak JIT, serta penunjukkan iliili untuk mengatur air irigasi. Partisipasi petani dalam evaluasi saat kegiatan berlangsung meliputi pembahasan tata letak JIT, perawatan JIT, pembagian JIT, hama wereng yang menyerang tanaman dan pembuatan JIT. Partisipasi petani dalam evaluasi akhir meliputi perawatan JIT, manfaat JIT, tata kelola air dan pembahasan sarana yang kurang maksimal untuk mendukung kegiatan. Partisipasi dalam pemanfaatan hasil pembangunan tergolong tinggi dan seluruh petani responden merasakan manfaat dari program Upsus Pajale.

Manfaat yang dirasakan petani antara lain penanaman dapat dilakukan secara serentak karena difasilitasi pemerintah, pengaturan air untuk keluar dan masuk menjadi mudah karena adanya JIT, indeks pertanaman dua kali tercapai, produksi meningkat dan kebutuhan air tercukupi.

Tabel 1. Rekapitulasi tingkat partisipasi petani dalam program Upsus Pajale

\begin{tabular}{llcc}
\hline \multirow{2}{*}{ Interval Skor } & Klasifikasi & \multicolumn{2}{c}{ Jumlah Responden } \\
\cline { 3 - 4 } & & Petani & $\begin{array}{c}\text { Persentase } \\
(\%)\end{array}$ \\
\hline $6,00-14,51$ & Rendah & 29 & 53,70 \\
$14,52-23,03$ & Sedang & 21 & 38,89 \\
$23,04-31,52$ & Tinggi & 4 & 7,41 \\
\hline Jumlah & & 54 & 100 \\
\hline Rata - rata : 18,64 (sedang) & & \\
\hline
\end{tabular}

Tabel 2. Sebaran hasil produksi petani sebelum Program Upsus Pajale

\begin{tabular}{clcc}
\hline \multirow{2}{*}{$\begin{array}{c}\text { Interval } \\
\text { Produksi }\end{array}$} & Klasifikasi & \multicolumn{2}{c}{ Jumlah Responden } \\
\cline { 3 - 4 } & & Petani & $\begin{array}{c}\text { Persentase } \\
(\%)\end{array}$ \\
\hline $0,95-4,63$ & Rendah & 42 & 77,78 \\
$4,64-8,31$ & Sedang & 11 & 20,37 \\
$8,32-12,00$ & Tinggi & 1 & 1,85 \\
\hline Jumlah & & 54 & 100 \\
\hline
\end{tabular}




\section{Faktor-faktor yang Diduga Berhubungan Dengan Partisipasi Petani}

\section{Produksi $\left(\mathbf{X}_{1}\right)$}

Produksi $\left(\mathrm{X}_{1}\right)$ menunjukkan hasil usahatani khususnya dalam penelitian ini adalah tanaman padi yang dilakukan oleh petani dalam satu musim tanam. Produksi bertujuan untuk memenuhi kebutuhan manusia untuk mencapai kemakmuran. Pada Tabel 2 menunjukkan bahwa sebagian besar petani yang menjadi responden dalam penelitian ini $(77,78 \%)$ memiliki hasil produksi padi yang rendah. Produksi padi di Kecamatan Rawa Jitu Selatan tergolong rendah dikarenakan tingginya serangan hama penyakit padi seperti Blass daun, Blass leher, ulat gulung, wereng cokelat, tikus dan serangan bakteri Xanthomonas Oryzae, tingginya kandungan air asin dilahan pertanian karena abrasi laut dan unsur $\mathrm{Fe}$ yang banyak terkandung di lahan sawah milik petani.

\section{Motivasi (X2)}

Motivasi adalah dorongan dari dalam diri petani untuk bertindak melakukan sesuatu sehingga mencapai tujuan tertentu dan diukur dengan indikator tingkat persistensi, devosi, tingkat aspirasi, tingkat kualifikasi dan sikap terhadap program. Pada Tabel 3 menunjukkan bahwa petani yang menjadi responden pada penelitian ini $(48,20 \%)$ memiliki tingkat motivasi yang tinggi dalam mengikuti Program Upsus Pajale. Rata-rata skor tingkat motivasi petani adalah sebesar 16,15 atau berada pada klasifikasi sedang.

Petani dengan tingkat motivasi yang tinggi tidak berputus asa, rela berkorban, bersungguh-sungguh, senantiasa membuat rencana dan target serta senantiasa puas dengan hasil yang dicapai. Contohnya, mereka tidak berputus asa dalam memberantas hama penyakit yang menyerang lahan padinya, angin yang merobohkan padi dan mengatasi lahan sawah yang mengandung unsur $\mathrm{Fe}$, serta petani berkorban waktu, tenaga, uang dan jiwa untuk mengatasi berbagai hambatan tersebut guna meningkatkan produksi. Petani yang berada diklasifikasi sedang dan rendah bersifat mudah putus asa, kurang berkorban, bersungguh-sungguh, membuat rencana dan target serta kurang puas dengan hasil yang dicapai.

\section{Perilaku Komunikasi Kelompok (X3)}

Perilaku komunikasi kelompok yaitu cara seseorang berkomunikasi dalam suatu kelompok.
Perilaku komunikasi kelompok dalam penelitian ini diukur melalui indikator, yaitu frekuensi komunikasi dalam kelompok, media komunikasi, informasi komunikasi, sikap terhadap informasi dan media yang digunakan untuk menyebarkan informasi. Keadaan perilaku komunikasi kelompok dapat dilihat pada Tabel 4. Tabel 4 menunjukkan bahwa sebagian besar petani yang menjadi responden pada penelitian ini $(72,20 \%)$ memiliki perilaku komunikasi kelompok yang rendah dalam mengikuti Program Upsus Pajale.

Rata-rata skor perilaku komunikasi kelompok petani adalah sebesar 9,09. Frekuensi komunikasi dalam kelompok masih tergolong rendah. Petani melakukan komunikasi dalam kelompoknya ratarata sebanyak 3 kali dalam satu bulan. Komunikasi yang dilakukan biasanya menggunakan brosur mengenai pupuk, selebaran yang diberikan dari penyuluh dan cukup banyak pula petani yang berkomunikasi tanpa menggunakan media. Komunikasi yang dilakukan memuat informasi mengenai pembahasan hama yang menyerang lahan, tindakan yang sebaiknya dilakukan, penentuan letak JIT, pemeliharaan JIT, jenis benih padi dan tata kelola air irigasi. Sikap petani terhadap informasi yang didapat hanya diterima dan disebarkan. Tidak semua petani menerapkan informasi tersebut karena petani tidak mau dan tidak mampu menerapkan informasi tersebut, seperti penggunaan pupuk yang mahal untuk pemberantasan hama. Karena rendahnya frekuensi petani dalam berkomunikasi kelompok, rendahnya penggunaan media yang digunakan dalam komunikasi, dan rendahnya informasi yang diberikan dalam komunikasi menyebabkan rendahnya pengetahuan, sikap dan keterampilan petani dalam menjalankan program Upsus Pajale. Petani akan berperilaku aktif dalam menjalankan suatu kegiatan jika petani tersebut mengetahui tujuan dan semua kegiatan yang akan dilakukan, sehingga petani akan terampil dalam melaksanakan kegiatan.

Tabel 3. Sebaran tingkat motivasi petani dalam mengikuti program Upsus Pajale

\begin{tabular}{llcc}
\hline \multirow{2}{*}{$\begin{array}{c}\text { Interval Skor } \\
\text { Motivasi }\end{array}$} & Klasifikasi & \multicolumn{2}{c}{ Jumlah Responden } \\
\cline { 3 - 4 } & & Petani & $\begin{array}{l}\text { Persentase } \\
(\%)\end{array}$ \\
\hline $11,2-13,8$ & Rendah & 4 & 7,40 \\
$13,9-16,5$ & Sedang & 24 & 44,40 \\
$16,6-19,2$ & Tinggi & 26 & 48,20 \\
\hline Jumlah & & 54 & 100 \\
\hline Rata-rata : 16,15 (sedang) & & \\
\hline
\end{tabular}


Tabel 4. Sebaran perilaku komunikasi kelompok

\begin{tabular}{llcc}
\hline \multirow{2}{*}{ Interval Skor } & Klasifikasi & \multicolumn{2}{c}{ Jumlah Responden } \\
\cline { 3 - 4 } & & Petani & $\begin{array}{c}\text { Persentase } \\
(\%)\end{array}$ \\
\hline $6,50-8,70$ & Rendah & 39 & 72,20 \\
$8,80-11,00$ & Sedang & 13 & 24,10 \\
$11,10-13,30$ & Tinggi & 2 & 3,70 \\
\hline Jumlah & & 54 & 100 \\
\hline Rata-rata $: 9,09$ (sedang) & & \\
\hline
\end{tabular}

\section{Intensitas Mengikuti Sosialisasi Program (X4)}

Intensitas mengikuti sosialisasi program dalam merupakan frekuensi petani mengikuti sosialisasi program. Indikator pengukuran intensitas mengikuti sosialisasi program adalah frekuensi mengikuti sosialisasi.

Tabel 5 menunjukkan bahwa sebagian besar petani yang menjadi responden dalam penelitian ini $(51,85 \%)$ memiliki intensitas mengikuti sosialisasi program tergolong sedang. Rata-rata skor mengikuti intensitas sosialisasi program adalah sebesar 3,53. Intensitas mengikuti sosialisasi program yang tinggi ditunjukkan dengan frekuensi petani mengikuti sosialisasi tinggi dan materi yang disampaikan beragam, sedangkan intensitas mengikuti sosialisasi program yang sedang atau rendah ditunjukkan dengan rendahnya frekuensi petani mengikuti sosialisasi dan materi yang disampaikan tidak beragam. Rendahnya intensitas petani mengikuti sosialisasi program disebabkan karena kondisi fisik petani kurang memungkinkan untuk menghadiri sosialisasi, waktu pelaksanaan sosialisasi yang bersamaan dengan aktivitas petani dan materi yang diberikan saat sosialisasi program hanya mengulas kembali materi sebelumnya, seperti cara pemberantasan hama penyakit menggunakan pupuk kimia tanpa ada inovasi baru dari penyuluh. Frekuensi intensitas mengikuti sosialisasi program yang rutin diadakan oleh penyuluh akan lebih mendorong tingkat partisipasi petani dalam melaksanakan Program Upsus Pajale.

\section{Hasil Pengujian Hipotesis}

Analisis hubungan antara variabel $\mathrm{X}$ yang meliputi faktor produksi, tingkat motivasi, perilaku komunikasi kelompok dan intensitas sosialisasi program dengan partisipasi petani yang dilihat dari akumulasi kegiatan partisipasi seperti partisipasi dalam perencanaan kegiatan, pelaksanaan kegiatan, pemantauan dan evaluasi serta pemanfaatan hasilhasil pembangunan. Kemudian dianalisis menggunakan uji korelasi Rank Spearman. Dapat dilihat pada Tabel 6 mengenai hasil analisis faktor- faktor yang diduga berhubungan dengan partisipasi petani.

\section{Hubungan antara Produksi Dengan Tingkat Partisipasi Petani dalam Program Upsus Pajale di Kecamatan Rawa Jitu Selatan}

Berdasarkan hasil pengujian hipotesis menunjukkan bahwa hubungan antara produksi usahatani padi petani dengan partisipasi petani dalam program Upsus Pajale diketahui berhubungan nyata. Hal tersebut berarti produksi usahatani padi petani ada hubungannya dengan partisipasi petani dalam Program Upsus Pajale. Rendahnya produksi padi di Kecamatan Rawa Jitu Selatan disebabkan karena lahan di Kecamatan Rawa Jitu Selatan mengandung banyak unsur $\mathrm{Fe}$ yang sulit diatasi, air asin yang masuk karena abrasi, serangan hama wereng, hama tikus, penyakit Blass dan hama putih palsu yang cukup tinggi pun menyebabkan rendahnya produksi padi di Kecamatan Rawa Jitu Selatan, terutama di Gapoktan Yudha Karya Jitu.

Hasil penelitian ini sesuai dengan hasil penelitian Sari, Yusak dan Sri (2013) mengenai hubungan antara partisipasi petani dalam program Sekolah Lapang Pengelolaan Tanaman Terpadu (SLPTT) dengan produksi dan pendapatan usahatani jagung di Nagori Pulo Bayu Kecamatan Hutabayuraja Kabupaten Simalungun yang menyimpulkan bahwa terdapat hubungan antara tingkat partisipasi petani dalam Program SL-PTT dengan produksi dan pendapatan di Nagori Pulo Bayu Kecamatan Hutabayuraja Kabupaten Simalungun.

Tabel 5. Intensitas mengikuti sosialisasi program Upsus Pajale

\begin{tabular}{llcc}
\hline \multirow{2}{*}{ Interval } & \multirow{2}{*}{ Klasifikasi } & \multicolumn{2}{c}{ Jumlah Responden } \\
\cline { 3 - 4 } & & Petani & $\begin{array}{c}\text { Persentase } \\
(\%)\end{array}$ \\
\hline $1,00-2,33$ & Rendah & 2 & 3,70 \\
$2,34-3,67$ & Sedang & 28 & 51,85 \\
$3,68-5,00$ & Tinggi & 24 & 44,45 \\
\hline Jumlah & & 54 & 100 \\
\hline Rata - rata : 3,53 (sedang) & \multicolumn{2}{c}{} \\
\hline
\end{tabular}


Tabel 6. Hasil analisis faktor-faktor yang diduga berhubungan dengan tingkat partisipasi petani

\begin{tabular}{lllll}
\hline \multicolumn{1}{c}{ Variabel X } & $\begin{array}{c}\text { Variabel } \\
\text { Y }\end{array}$ & $\begin{array}{c}\text { Koefisien } \\
\text { Korelasi }\end{array}$ & $\begin{array}{c}\text { Sig }(2- \\
\text { Tailed })\end{array}$ & $\begin{array}{c}\mathrm{t} \\
\text { Hitung }\end{array}$ \\
\hline - Produksi & & $0.403^{* *}$ & 0.003 & 3,176 \\
- Motivasi & & $0.223^{\text {tn }}$ & 0.105 & 1.649 \\
- Perilaku & & $0.544^{* *}$ & 0.000 & 4.675 \\
$\quad$ Komunikasi & Partisipasi & & & \\
$\quad$ Kelompok & Petani & & & \\
- Intensitas & & $0.351^{* *}$ & 0.009 & 3.524 \\
$\quad$ Sosialisasi & & & \\
$\quad$ Program & & & \\
\hline Keterangan : & & \\
rs : Penduga koefisien korelasi \\
**: Nyata pada taraf kepercayaan $99 \%(\alpha=0,01 \mathrm{t}$ tabel $=1,663)$ \\
tn : Tidak nyata pada taraf kepercayaan $95 \%$ dan $99 \%$
\end{tabular}

Hubungan antara Tingkat Motivasi Dengan Tingkat Partisipasi Petani dalam Program Upsus Pajale di Kecamatan Rawa Jitu Selatan

Berdasarkan hasil pengujian hipotesis diketahui bahwa tingkat motivasi tidak berhubungan dengan partisipasi petani. Petani masih enggan membuat rencana dan target, selain itu petani juga mudah berputus asa dalam menyikapi permasalahanpermasalahan di lokasi usahatani, misalnya permasalahan mengatasi lahan yang mengandung unsur $\mathrm{Fe}$, tanaman padi yang diserang hama wereng cokelat, ulat gulung, tikus, bakteri Xanthomonas Oryzae, masalah padi yang roboh karena tertiup angin, sulit mengatasi air asin yang masuk pada saat abrasi laut dan masalah hama putih palsu yang menyerang padi. Petani kurang mengetahui cara penanganannya, sehingga petani menunggu saran-saran yang diberikan oleh pengurus gapoktan ataupun dari penyuluh. Petani kurang aktif mencari informasi sendiri untuk usahataninya. Rendahnya hal-hal tersebut menyebabkan partisipasi petani dalam program Upsus Pajale tergolong rendah pula. Hasil penelitian ini sesuai dengan penelitian Monita (2015) tentang analisis tingkat partisipasi masyarakat terhadap pelaksanaan program desa vokasi di Desa Pulutan Wetan Kecamatan Wuryantoro Kabupaten Wonogiri yang menyimpulkan bahwa tingkat motivasi masyarakat berhubungan dengan tingkat partisipasi.

\section{Hubungan antara Perilaku Komunikasi Kelompok dengan Tingkat Partisipasi Petani dalam Program Upsus Pajale di Kecamatan Rawa Jitu Selatan}

Berdasarkan hasil pengujian hipotesis diketahui bahwa terdapat hubungan antara perilaku komunikasi kelompok dengan partisipasi petani dalam Program Upsus Pajale. Frekuensi komunikasi kelompok yang sering dilakukan akan lebih mendorong petani meningkatkan pengetahuan, sikap dan keterampilan mengenai Program Upsus Pajale.

Frekuensi petani berkomunikasi dalam kelompok cukup tinggi, baik secara langsung, ataupun dengan menggunakan Handphone, selebaran tentang informasi pupuk, buku tentang hama penyakit dan kertas selebaran yang berisi informasi mengenai hama dan penyakit pada tanaman padi. Petani mendapat berbagai informasi dari berkomunikasi dalam kelompok tersebut, antara lain mengenai pengendalian hama penyakit pada tanaman padi berupa wereng, tikus, ulat gulung dan bakteri Xanthomonas Oryzae. Setelah petani mendapatkan informasi tersebut, mereka lalu menerima dan menyebarkannya kepada petani lain baik tanpa menggunakan media ataupun dengan menggunakan media seperti handphone, selebaran dan buku. Semakin tinggi tingkat pengetahuan, sikap dan keterampilan petani terhadap suatu kegiatan, maka akan semakin tinggi pula partisipasi petani. Hasil Penelitian ini sesuai dengan penelitian Lestari (2012) yang menyimpulkan bahwa perilaku komunikasi kelompok berhubungan dengan tingkat partisipasi petani dalam kegiatan Sekolah Lapang Pengelolaan Tanaman Terpadu di Desa Gerung Utara Kecamatan Gerung Kabupaten Lombok Barat.

\section{Hubungan antara Intensitas Mengikuti Sosialisasi Program dengan Tingkat Partisipasi Petani dalam Program Upsus Pajale di Kecamatan Rawa Jitu Selatan}

Berdasarkan hasil pengujian hipotesis diketahui bahwa terdapat hubungan antara intensitas mengikuti sosialisasi program dengan tingkat partisipasi petani dalam Program Upsus Pajale. Intensitas mengikuti sosialisasi program akan mendorong partisipasi petani dalam melaksanakan Program Upsus Pajale. Intensitas rata-rata petani mengikuti sosialisasi program adalah sebanyak lima kali dalam satu musim tanam. Rendahnya intensitas petani mengikuti sosialisasi program disebabkan karena kondisi fisik petani kurang memungkinkan untuk menghadiri sosialisasi, waktu pelaksanaan sosialisasi yang bersamaan dengan aktivitas petani dan materi yang diberikan saat sosialisasi program hanya mengulas kembali materi sebelumnya, seperti cara pemberantasan hama penyakit menggunakan pupuk kimia tanpa ada inovasi baru dari penyuluh. Hasil penelitian ini 
sejalan dengan penelitian Lisbet (2011) dalam penelitiannya mengenai faktor yang mempengaruhi tingkat partisipasi masyarakat dalam kegiatan perbaikan prasarana jalan di Desa Megamendung, Bogor yang menyimpulkan bahwa intensitas mengikuti sosialisasi kegiatan berhubungan dengan tingkat partisipasi.

\section{KESIMPULAN}

Pelaksanaan program Upsus Pajale di Kecamatan Rawa Jitu Selatan meliputi kegiatan pembangunan dan pemeliharaan jaringan irigasi tersier, penyediaan bantuan benih, penyediaan bantuan pupuk, serta penyediaan alsintan. Rata-rata tingkat partisipasi petani terhadap program Upsus Pajale di Kecamatan Rawa Jitu Selatan tergolong sedang $(11,07 \%)$. Faktor-faktor yang berhubungan dengan tingkat partisipasi petani dalam Program Upsus Pajale adalah produksi, perilaku komunikasi kelompok dan intensitas sosialisasi program.

\section{DAFTAR PUSTAKA}

Hartanti, Wiwied, Satria NL dan Hasudungan B. 2012. Dampak pertambahan penduduk, akses pangan dan usaha pengentasan kemiskinan terhadap jumlah penduduk miskin di Sumatera Utara. Jurnal Agribisnis. Vol. 10 (4) : 5-8.

Kuncoro EA. dan Riduwan. 2008. Cara Menggunakan dan Memakai Analisis Jalur. Alfabeta. Bandung.

Lestari D. 2012. Analisis partisipasi petani dalam Kegiatan Sekolah Lapang Pengelolaan
Tanaman Terpadu (SL-PTT) di Desa Gerung Utara Kecamatan Gerung Kabupaten Lombok Barat. Media Bina Ilmiah, Vol. 6 (3) : 4-7.

Lisbet JG. 2011. Faktor yang Mempengaruhi Partisipasi Masyarakat dalam Kegiatan perbaikan prasarana jalan di Desa Megamendung, Bogor. Skripsi. Institut Pertanian Bogor. Bogor.

Mardikanto T. 2010. Konsep Pemberdayaan Masyarakat. Tiga Serangkai. Surakarta.

Monita RP. 2015. Analisis Tingkat Partisipasi Masyarakat Terhadap Pelaksanaan Program Desa vokasi di Desa Pulutan Wetan Kecamatan Wuryantoro Kabupaten Wonogiri. Skripsi. Universitas Muhammadiyah Surakarta. Surakarta.

Saputra YE. 2015. Partisipasi Masyarakat dalam Program Pembangunan Desa. Laporan Studi Pustaka. Departemen Sains Komunikasi dan Pengembangan Masyarakat Fakultas Ekologi Manusia Institut Pertanian Bogor.

Sari M, Yusak M dan Sri FA. 2013. Hubungan antara partisipasi petani dalam Program Sekolah Lapang Pengelolaan Tanaman Terpadu (SL-PTT) dengan produksi dan pendapatan usahatani jagung di Nagori Pulo Bayu Kecamatan Hutabayuraja Kabupaten Simalungun. Wacana. Vol. 2 (6) : 5-10.

Siegel. 1997. Statistik Non Parametrik Untuk Ilmu Sosial. PT Gramedia Pustaka Utama. Jakarta.

Tangkilisan HNS. 2007. Manajemen Publik. Grasindo. Jakarta. 